\title{
Chapter 2 \\ The Copenhagen School and Beyond. A Closer Look at Securitisation Theory
}

\subsection{Introduction}

The aim of the chapter is to provide a closer look at the Copenhagen School of security ${ }^{1}$ and its proposition of securitisation theory. In doing so, it will focus on the discussion on the main conceptual building blocks of the theory, outlining their characteristics and critique reflected in the current securitisation literature. For the past years, the Copenhagen School has inspired a plethora of studies and theoretical reflections on different modes and characteristics of the construction of security, becoming particularly relevant for migration-security nexus research (Huysmans, 2006; Lazardis, 2011; Leonard \& Kaunert, 2019; van Munster, 2009). In this book the Copenhagen School, along with criticism of it, serves as a point of refence for further elaboration of the framing centred securitisation and discussion on the intertwining of security logics in the process of intersubjective construction of security. The chapter is structured as follows. The first section provides an overview of the mechanics of the securitisation theory, defining its key constituents - speech act, logic of exception, and actor-audience interaction. Further, it moves to discussion on each of these elements, elaborating their specific role within the theory, but also outlining their specific limiting effects on securitisation research. The last section discusses how the debate on securitisation has been expanding, opening the door to new conceptual frameworks as well as elaborations of security.

${ }^{1}$ The term was first introduced by Bill McSweeney (in McSweeney, 1996). 


\subsection{The Concept of Securitisation}

In the past 30 years, the Copenhagen School and its securitisation theory have become increasingly relevant in the academic discussion on the widening of security (moving beyond the military) and deepening the pool of its referent objects (moving beyond the monopoly of the state as something that can be threatened) (Buzan \& Hansen, 2009, p. 187). The beginnings of the theory can be traced back to a series of articles by Barry Buzan and Ole Wæver (Buzan, 1997; Buzan \& Wæver, 1997; Wæver, 1995a, b; Wæver et al., 1993), which eventually resulted in a seminal publication entitled Security: A New Framework for Analysis (Buzan et al., 1998). The securitisation framework as presented by the Copenhagen School aligns with the constructivist approach, committing to the discursive and linguistic turn in International Relations and security studies. It builds upon the notion that "language is not only concerned with what is 'out there', as realist and neorealist assume, but is also constitutive of the social reality it describes" (Balzacq, 2010, p. 56). The Copenhagen School argues that security is not a given but it is constructed through inter-subjective social and discursive interactions between powerful actors who propose definitions of threats and relevant audiences who acknowledge these definitions (Buzan et al., 1998). Over the years, securitisation theory has proved to be an attractive framework and a starting point for contemporary scholars, who are challenging the notion of a materialist ontology and uncovering the philosophy, methods and dynamics hiding behind processes, which "push" or "pull" issues, actors, or processes into the realm of security (see Bigo, 2014; Bourbeau, 2015; Neal, 2009).

Even though securitisation is commonly described as a bridging theory, encompassing elements of constructivist and mainstream security studies, its founding fathers prefer to describe it as an example of "radical constructivism" (Buzan et al., 1998). In the broadest terms, securitisation theory allows one to understand how security is constructed with language, and more specifically performative utterances - speech acts (Wæver, 1995b, p. 55). As opposed to the realists, the Copenhagen School is not concerned with identifying objectively construed "real" threats and consequently does not engage in the discussion on the materiality of security (Buzan \& Wæver, 1997). Instead, it allows one to peek behind the curtain of security and look at it as a "quality actors inject into issues by securitising them, which means staging those issues on the political arena in the specific way that makes them acceptable as a security problem, sanctioning security actions and defensive moves" (Buzan et al., 1998).

With securitisation theory, Buzan and his colleagues outline a framework, which combines security as an inter-subjective social construct with elements of Austin's speech act and Schmitt's idea of "exception" (Buzan et al., 1998). In his early writings on securitisation theory, he proposes treating security as a speech act, a performative utterance which when spoken by a relevant actor (i.e. securitising actor) brings security into being. As he puts it:

By saying it, something is done (as in betting, giving a promise, naming a ship). By uttering "security" a state-representative moves a particular development into a specific area and 
thereby claims a special right to use whatever means are necessary to block it (Wæver, 1995b, p. 55).

It the later iteration of the theory, Buzan and Wæver (1997) put a stronger emphasis on the rhetorical structure of speech acts, underlining the importance of raising the securitised issue above the threshold of so-called "normal politics". Here, powerful societal actors produce security discourses, by framing an issue as an existential threat to a specific referent object (a valued object that require protection). In other words, the securitisation process is concerned with

the staging of existential issues in politics to lift them above politics. In security discourse, an issue is dramatized and presented as an issue of supreme priority; thus, by labelling it as security, an agent claims a need for and a right to treat it by extraordinary means (Buzan et al., 1998p. 26).

According to the Copenhagen School, the fact that powerful societal actors use securitising speech acts to declare a particular issue, dynamic or actor to be an existential threat does not by itself produce security. Here, speech acts represent securitising moves, an attempt, which needs to gain societal and political saliency and more importantly the approval of a relevant audience (e.g. wider society) (Buzan et al., 1998). It is the audience's acceptance that ultimately empowers securitising moves, turning them into an inter-subjectively constructed threat (Côté, 2016). The Copenhagen School builds on the assumption that securitisation is not uniform across different issues. In order to better understand specific nuances of securitisation, it introduces the concept of security sectors, which reflect different dynamics of securitisation, including the way its constitutive elements, such actors, audiences, referent objects and vulnerabilities to security, are defined and incorporated in the act of constructing security (Buzan et al., 1998). In this regard, securitisation builds on previous work by Buzan (most notably his book People, State and Fear) indicating five distinctive areas, corresponding with different aspects security, namely: the military, environmental, economic, societal and political (Buzan, 1991; Buzan et al., 1998).

This general overview of the framework allows one to isolate three building blocks, which underlie securitisation, namely: (1) speech act, (2) logic of exception, (3) actor-audience interaction. In the next part of this chapter, I will discuss these elements of the theory, focusing on their unique features, functions as well as critique within a broader securitisation literature. This discussion will serve as a point of reference for further elaboration of the securitisation framework, as applied in this book.

\subsection{Securitisation and the Speech Act Approach}

As already indicated, securitisation theory is invested in John L. Austin's and John Searle's theory of speech acts, translating the idea of performativity of language to the concept of security (Austin, 1975; Searle, 1969). According to Austin, language 
is not comprised solely of statements that carry content and can be judged in terms of true or false but is performative and introduces change into social reality (Austin, 1975, p. 10). Of course, not every utterance has performative power, as it needs to meet certain conditions and requirements. To describe this, Austin gives an example of a wedding. Here, an authoritative figure (e.g. a priest) creates a social fact of marriage though a series of utterances that culminate in the words "I pronounce you husband and wife" (Austin, 1975, p. 13). In this sense, the power of speech is based on the following elements. Firstly, the physical act of speech itself (i.e. locution) and the conventionalised script which the speaker has to follow in order to infuse the utterances with performative power (i.e. illocution); secondly, the power of the figure that engages in performing the speech act (i.e. authority); lastly, the effect of the speech on the audience, reflected, for example, in fulfilment of an order (i.e. perlocution) (Austin, 1975, p. 17; Rosaldo, 1982).

In the Copenhagen School approach, the locutionary and illocutionary aspects of speech acts are supposed to create a rupture in the common understanding of an issue and propose its introduction into the framework of security (Vuori, 2008). In this vein, the script of securitising speech act should incorporate two key elements a definition of an existential threat and a referent object (Stritzel, 2007). The definition of an existential threat is necessary as it introduces a sense drama and extreme urgency that has the potential to validate extraordinary measures and suspension of normal politics (Vuori, 2008, p. 70). The referent object should be, at least to some extent, commonly acknowledged as socially relevant and refer, for instance, to shared values, identities, or issues that resonate with a wider part of the targeted audience (Buzan et al., 1998). Keeping these two elements in mind, a securitising actor has a chance to produce a successful securitising speech act that is commonly accepted as a legitimate and dominant security problem requiring exceptional security measures.

Apart from the conventionalised speech itself, the authority of the speaker plays an important role in the speech act approach to security. The Copenhagen School describes securitising actors as "those who speak security" - a person, or a group, who performs the securitising speech acts from the position power that can substantiate introduction of extraordinary measures (Buzan et al., 1998, p. 40). In this regard, Buzan and Wæver point towards broadly understood political elites, governmental agencies, bureaucrats, and pressure groups, that hold a special position in defining and implementing security (Wæver, 1995b, pp. 49-50). This catalogue can be expanded with any actor, who is expected and able to define threats to the referent objects valued by the groups they represent or belong to (Williams, 2003). Buzan and Wæver argue that the actors are usually not the referent objects, but they regularly claim to speak on their behalf (Buzan et al., 1998, p. 40). A popular example of such a securitising behaviour is a political party or a non-governmental organisation producing security speech acts in defence of national identity (Huysmans, 2006) or religious values (Bagge Laustsen \& Wæver, 2000). In such situations, especially political actors often apply securitisation as an instrument for gaining 
control over specific areas of social and political life, dominating the discourse, setting out the tone for further actions and policies (Skleparis, 2016, pp. 97-99).

Regardless the power of securitising actors and the contents of speech acts, the inter-subjective character of the theory requires perlocution, in other words, the consent of empowering audiences (McDonald, 2008). As Buzan and his colleagues indicate, the element of

security is not held in subjective and isolated minds; it is a social quality, a part of discourse, socially constituted, inter-subjective realm. For individuals or groups to speak security does not guarantee the success (Buzan et al., 1998, p. 31).

In this vein, the Copenhagen School does not leave much space for discussion about the role of the audience, clearly indicating that "successful securitization is not decided by the 'securitizer' but by the audience of the security speech act" (Buzan et al., 1998, p. 31). The element of audience is visibly problematic from the analytical point of view. Even though the theory clearly indicates what the audience is supposed to do, it does not elaborate on who or what the audience is (Jarvis \& Legrand, 2017, pp. 150-151).

Critics of the speech act approach point out that the Copenhagen School does not equally embrace the locutionary, illocutionary and perlocutionary dimensions of the theory. It is evident that the locutionary and illocutionary aspects of speech act play more significant role in securitisation framework. It is reflected in the static and decisionist interpretation of securitisation theory, which has been promoted by the Copenhagen School. Indeed, it has been explicitly indicated that "the structure of the theory is organised around securitisation as an act, a productive moment (...)" (Wæver, 2011, p. 468). This act or moment of securitisation is predominantly built around the articulation of the speech by an actor, who enjoys control over securitisation. As Wæver points out in his earlier writings, "something is a security problem when the elites declare it to be so" (1995b, pp. 54-55). In this sense, the Copenhagen School depicts securitisation more as a directive or static event, unnecessarily marginalising iterative and incremental processes that are so typical for the social construction of reality. Further, the Copenhagen School strongly emphasises and elaborates upon the role of securitising actors, consequently downplaying the perlocutionary dimension of the theory and the role of audience. As Stritzel puts it:

the more emphasis is put on the notion of 'illocution', the less important the concept of 'audience' seems to become, as the modus of security could be thought of as being constituted by the illocutionary utterance itself (Stritzel, 2011, p. 349).

In the light of this criticism, it could be argued that the Copenhagen School's proposition of securitisation theory is somewhat paradoxical (Balzacq, 2005; Floyd, 2007). It is supposed to be radically constructivist and inter-subjective, but the original reading of the theory puts much emphasis on speech act decisions and selfreferential elements. It is not completely clear where the real centre of gravity of securitisation theory lies. 


\subsection{Securitisation the Logic of Exception}

Securitisation theory is devoted to explaining the process of creating security out of objects, issues and dynamics that normally "existed" outside security frameworks (Bourbeau, 2015). It is dedicated to studying how security "gains new grounds" and widens its scope through discursive practices. Yet, this raises concerns of turning "security" into a concept which encompasses so many areas that it in the end becomes blurred and empirically useless. As Peoples and Vaughan-Williams point out, that there are "intellectual and political dangers in simply tacking the word security onto an ever wider range of issues", making the concept of security too broad and empirically useless (Peoples \& Vaughan-Williams, 2015, p. 93). The Copenhagen School, trying to escape this "making everything a security" trap, introduces conceptual limitations linking securitisation to the Schmittian idea of "exception" as a way of breaking "normal politics" and entering into realm of security (Buzan et al., 1998; Buzan \& Wæver, 1997). It conceptualises normal politics in terms of standardised everyday forms of political interaction that allow for contestation and deliberation over an issue in the public space within the bounds of normative and causal procedures (Pram Gad \& Lund Petersen 2011:320). As Waever puts it, "the place of security in the theory is as an anti-politics or the politically constituted limit to politics" (Wæver, 2011, p. 478). In this way, the Copenhagen School looks at the process of constructing security as locked between securitisation (introduction of an issue to non-political exceptionality) and desecuritisation (reintroduction of an issue to normal politics) (Wæver, 1995b).

Indeed, the securitisation framework is very much concerned with the idea of security based on an exception, driven by "existential threats and the radical enmity between friends and foes" (Rothe, 2016, p. 48). In Schmittian philosophy, "'the exception' is a situation of radical danger and contingency for which no prior law, procedure or anticipated response is adequate, it is a perilous moment that exceeds the limits of precedent, knowledge, legislation and predictability" (C.A.S.E., 2007, p. 465). Exception-driven security introduces a constitutive antagonism, which constantly threatens a political community and prepares it for the possibility of introduction of exceptional measures and the breaking of the established normative and legal order in the name of the common security (Pram Gad \& Lund Petersen, 2011, p. 318). For the Copenhagen School securitisation is a form of radicalisation and "extreme politicisation", marking a moment when an issue breaks the barrier of normal politics, ends the political discussion and is handled with extraordinary measures (Patomäki, 2015). Consequently, an issue can pass through different forms of politicisation before reaching the level of security. As Buzan and his colleagues explain:

in theory, any public issue can be located on the spectrum ranging from non-politicized (meaning the state does not deal with it and it is not in any other way made an issue of public debate and decision) through politicized (meaning the issue is part of public policy, requiring government decision and resource allocations or, more rarely some other form of communal governance) to securitised (meaning the issue is presented as an existential 
threat, requiring emergency measures and justifying actions outside the normal bounds of political procedure) (Buzan et al., 1998, pp. 23-24).

According to Schmitt, it is the sovereign who decides on the exception and consequently the direction of the securitisation process (Schmitt, 2010, p. 5). The basis for such a decision is the identification of existential threats, external to the inner order and the consequent demarcation between friends and enemies (Rothe, 2016, p. 48). This decision of taking politics into "security mode" ascribes nearly unlimited and unconstrained prerogatives to the political authority, which acts in the name of survival of the sovereign (Pram Gad \& Lund Petersen, 2011, p. 318). Authority thus construed often plays the role of a securitising actor, holding control over groups' identity as a political community, stimulating its sense of insecurity and strengthening or weakening its coherence based on the perceived threats and realised antagonisms (Williams, 2003, p. 518).

The Copenhagen School does not elaborate on the mechanics and modes of descuritisation. Some of the most pivotal research in this area is presented by Huysmans, who uses the example of migration to show three possible pathways of downgrading already securitised issues $(1995,1998)$. He suggests the existence of an "objective strategy" (framing migrants an non-threatening to "our" identity); a "constructivist strategy" (developing a broader understanding of the phenomenon of migration, so that further securitising moves have a lesser impact on the common perception of immigrants); and a "deconstrucitivist strategy" (desecuritisation through interpersonal experiences with migrants and breaking down exclusionary divisions of "us" and "them") (Huysmans, 1995, pp. 66-67). Nonetheless, the literature also indicates the cases of "entrenched" or "deep" securitisations, where security narratives are so imbued into the very definition of an issue or a group (e.g. ethnic groups) that it becomes extremely problematic to develop strategies for its desecuritisation (Abulof, 2014).

This brings the discussion to the point concerned with the normative dimension of the securitisation theory, focusing on the question whether it is a "negative" concept. The Copenhagen Schools is quite clear about this, indicating that the process of constructing security indeed has a "dark side" (Wæever, 1995b, p. 64). In some ways, securitisation may be obstructive to developing creative policy solutions, limiting the political space "required to thinking through often complex issues and instead introducing an unhelpful degree of enmity and urgency" (Peoples \& Vaughan-Williams, 2015, p. 100). Wæver uses an example of environmental security, arguing that statist solutions driven by the logic of security might lead to unnecessary centralisation and militarisation of environmental issues (1995b). He also points out societal dangers, associated with increased securitisation such as increase of hate speech, discriminatory discourses and consequent reinforcement of antagonisms driven by "us" versus "them" logic (1995b, p. 65). This is when in most cases desecuritisation becomes a more desirable and effective option, downgrading a problem from security to the world of process-type remedies on "normal political deliberation and haggling" (Wæver, 1999, p. 335). 
The rule of exceptionality has been widely contested in the securitisation literature, generating substantial criticisms on three interrelated grounds. Firstly, it has proven to be empirically limiting. By arguing that successful securitisation moves an issue outside normal democratic politics, the Copenhagen School unnecessarily restricts itself to domestic norms and democratic governments, limiting the applicability of the theory within non-state, non-democratic and international contexts (Stritzel, 2011; Wilkinson, 2007). This problem is specifically visible in research on securitising practices in transnational settings, such as the European Union, where the political process is not attuned to the state of democratic normalcy, but embedded in various forms of high level and technocratic politics (Huysmans, 2000; Sperling \& Webber, 2019; van Munster, 2009). Abrahamson voices similar concerns arguing that "exceptional securitization does not fully capture the dominant mode of security politics, which is most often gradual and incremental, with issues only rarely moving directly from normalcy to emergency" (Abrahamsen, 2005, p. 71). Secondly, exceptionality can never fully eliminate the political haggling or political debate from the securitisation process. As Huysmans indicates, even exceptionalist securitisation is never simply an imposition of the end of normal politics as it "always entails the opening up of a political terrain of contestation of democratic political organisation and authorisation" (Huysmans, 2014, p. 69). It is a process, which brings into play various actors and political rationalities, engaging them in contestation of exceptionality of the situation.

Thirdly, due to the premise of exceptionality, the Copenhagen School tends to apply the realist vocabulary of security, closing the theory to alternative notions of security and securitisation. Indeed, contemporary security practice has much less in common with exceptional politics and can be more associated with, for instance, humanitarianism or the concept of risk and the logic of governance reflected in long-termism and precautionary measures (Corry, 2012, p. 248). In this regard, exceptional securitisation ignores a whole plethora of security practices and discourses that operate below the threshold of exceptionality, but still remain in the realm of security (Lund Petersen, 2012; Rasmussen, 2006).

\subsection{Securitisation and the Audience-Actor Interaction}

The third building block of securitisation theory, the conceptualisation of audience, is also rather problematic as the Copenhagen School does not offer any substantial definition or discussion on this matter. Audience can be intuitively defined as the society or a different entity ${ }^{2}$ capable of accepting and legitimising definitions of existential threats and the consequential introduction of exceptional security measures (Côté, 2016, p. 548). This rather ambiguous conceptualisation

\footnotetext{
${ }^{2}$ Among others: government branch (Salter, 2008b), technical experts (Rothe, 2016), international community (Vaughn, 2009), local society (Buraczyński, 2015).
} 
has generated some confusion in the securitisation literature, resulting in vigorous discussion on the criteria of identification of relevant audience(s) (Salter, 2008b; Vaughn, 2009), its interaction with powerful actors (Côté, 2016) and modes of acceptance of security narratives and measures (Buraczyński, 2015; Stritzel \& Chang, 2015).

In order to identify a relevant audience in securitisation research, one first has to understand what an audience actually does. In the Copenhagen School, the role of an audience is construed as mostly passive and conceptualised around two essential functions: listening and reacting (Rothe, 2016, p. 35). Audience as "listeners" can be described as "a strategic resource that has to be won over" for the successful finalisation of the securitising move (McSweeney, 1996). In the traditional reading of the theory "audience is there to enjoy the show" or "sit and listen", while the real spectacle is controlled by powerful actors, who woo the audience with various methods and attractive scripts in order to secure the favourable reception of the securitising act (Stritzel, 2012). This leads to the second, and key, function of audience, which is reacting to securitising moves. The Copenhagen School identifies two types of audience responses - acceptance and non-acceptance of proposed threat definitions and security measures (Buzan et al., 1998:43). Here, audience enjoys rather limited influence over the process, with no particular ways of expressing more nuanced reactions to securitising moves. Referring to this traditional conceptualisation, Côté argues that audience is in fact an "agent without agency", stripped of any real possibility of influencing the actor and doing what it is supposed to, that is engage in inter-subjective construction of security (2016). This limitation is partly recognised by Buzan et al., who point out that

one danger of the phrases 'securitization' and 'speech act' is that too much focus can be placed on the acting side, thus privileging the powerful while marginalizing those who are the audience and judge of the act (Buzan et al., 1998, p. 41).

Indeed, without further conceptualisation of audience, securitisation risks becoming more of a self-referential directive produced by securitising actors, than a site of negotiations and an inter-subjective process (Balzacq, 2005, pp. 179-180). One of the "ways out" would be strengthening and exploring the perlocutionary effects of security speech acts and more meaningful incorporation of the concept of audience into the analytical scheme. This, however, would necessitate a reconfiguration of securitisation theory in terms of power and agency that could be ascribed to the involved agents, as well as the repositioning of actors and audiences in the framework.

The traditional idea of audience has sparked a lot of criticism and fruitful discussions on the role, definition and interaction of relevant audience and securitising actors. The main line of argument is the extent of power that should be identified with audience. Numerous researchers argue that without power and agency audience is incapable of playing its part in the securitisation process (Balzacq, 2011; Côté, 2016; Stritzel, 2012). It has to be an agent, which has a standing in political and societal contestation of the problems. In this sense, audience should have agency and the means to challenge definitions and measures proposed by powerful actors, beyond a simple "yes" or "no" (Emerson, 2017). In this approach, 
securitisation scholars, when identifying audience, look for powerful agents such as the international community, scientific community, or development aid donors, who have some positional power and an opportunity to shape the way security problems are construed and dealt with (Côté, 2016; Salter, 2008a; Vaughn, 2009).

On the other hand, some scholars make an interesting case against devoting that much attention to audience and its responses to securitising moves (Floyd, 2007; Taureck, 2006). Floyd argues that the recent fixation on the power of an audience may in fact deteriorate the real picture of securitisation and lead to false results (2016, pp. 689-691). Sometimes, powerful actors do not engage in meaningful interactions with their potential audiences. This is because at times securitising actors do not need an audience to move forward with their specific definition of a threat and implementation of security measures (Floyd, 2016, p. 692). In certain political contexts, especially non-democratic regimes, an audience may be unnecessary for the success of the process (Taureck, 2006). A similar situation can also be observed in policymaking contexts, where an issue may be securitised with policy tools and security actions without any specific audience-actor interaction (Sperling $\&$ Webber, 2019). As Taureck notes, in many types of securitisations, the incorporation of audience is not obligatory as it creates persistent theoretical and empirical complications (2006, p. 55). In this regard, Floyd goes as far as proposing that, if the context allows it, a researcher should consider removing the concept of audience from his/her securitisation framework and focus on exploration of different types of securitising actors (Floyd, 2016).

The securitisation literature does not really offer any coherent guidelines as to how audience and its interaction with powerful actors should be viewed. There is a growing body of research that shows that the nature of interaction between different audiences and actors should be treated as highly context sensitive and flexible in nature (Bourbeau, 2011; Stritzel, 2007; Wilkinson, 2007). For example, drawing on Goffman's work, Salter puts forward the idea that there are different types of audiences corresponding with different types of settings (e.g. political, technocratic, scientific) and that they vary in degree of power, agency and tools that allow them to engage powerful actors and influence the process (2008b). In a similar tradition, Kaunert and Leonard argue that it is necessary to distinguish different types of audiences which are engaged by securitising actors (2013). Depending on the situation, they may relate to and interact with each other in the production of security meanings and responses to threats (e.g. academics may collaborate with the media), potentially increasing their agency and role in the construction of security.

\subsection{Conclusion: Moving Forward with Securitisation Theory}

The Copenhagen School has created a unique intellectual space for discussion of the construction of security, expanding our understanding of how specific issues have been incorporated and used within international and national security frameworks. Building on criticism and theoretical debates, securitisation scholarship has 
been dynamically expanding, moving beyond the traditional theory as proposed by the Copenhagen School. Numerous scholars have been reaching out to other disciplines and theoretical traditions, supplementing, deconstructing and reconstructing securitisation theory, developing their own "schools" and methodologies (Bigo \& McCluskey, 2018; C.A.S.E., 2006; Hansen, 2011; Wæver, 2004). Consequently, securitisation scholarship has evolved into a diverse research programme exploring a variety of securitising practices and loci, at the same time providing a better understanding of processes of constructing security and threats.

The biggest revision of securitisation theory has been introduced and promoted by the Paris School. This sociological model of securitisation distances itself from speech act and the linguistic aspects of the original theory. Instead, it commits to the idea of securitisation as driven by security practice, which is institutionalised through repetitive actions and the interaction of security actors within the field of security (Balzacq, 2010, p. 13). As argued by Bigo,

it is possible to securitise certain problems without speech or discourse and the military and the police have known that for a long time. The practical work, discipline and expertise are as important as all forms of discourse (Bigo, 2000, p. 194).

The Paris School argues that securitisation does not always require definition and existential threats, drama and breaking from normal politics. It may take place though routine, over time and, on some occasions, even outside political discourse (Bigo, 2014). In this regard, the sociological take on securitisation breaks not only with the linguistic approach but also the idea of exceptionality of security. Here, security operates below the threshold of extraordinary measures, being embedded in normalised security practices such as policing, surveillance and control. For this reason, in the Paris School, securitising actors do not necessarily have to be authoritative or in position of power that allows them to shape collective understanding of security. They can be mundane practitioners, such as police and military forces, customs officers or humanitarian workers, who "manage unease" by constituting a security field within which specific problems such as migration or climate change are framed and practiced as threats to security (Bigo, 2002, pp. 63-65).

Bigo's work has opened up the securitisation framework to a more contextsensitive, processual thinking about the construction of security. In this regard, new perspectives have come to light. For instance, Strizel proposes viewing securitisation through the lenses of translation, proposing radically processual interpretation using the concept of translation (2011). Here, securitisation is treated as a productive rearticulation of the meaning of security in a new locale. In a different interpretation, Rothe reinvents securitisation using hegemonic discourse as a point of reference (2016). He builds on poststructuralist arguments and proposes treating securitisation as a process embedded in larger governmental landscapes, driven by the struggle between discourse coalitions which problematise novel issues as security problems. Leonard and Kaunert look at securitisation from the angle of policy studies, building on a policy venue perspective and underlining the importance of institutional settings and historical contextual factors influencing the construction of security (Leonard \& Kaunert, 2019). Of course, the list of new contributions to 
securitisation studies is much more exhaustive and diverse. The contemporary literature on securitisation is burgeoning with new ideas and reconceptualisations of the theory in an attempt to make it better aligned with different modes of discourse and practice (including technology-driven) and ever dynamic complexities that accompany social construction of security (Jeandesboz, 2016).

That being said, this diversity of approaches has a certain "blind spot" which is reflected in its commitment to specific security logics, primarily existential security and risk, that underlie different perspectives on securitisation (Watson, 2012, p. 182). This is specifically visible in the migration-security nexus literature. On one hand, some scholars focus on elites and their political discourses revolving around fear, exceptional understanding of security and different forms of extraordinary measures and policies proposed in political debates (Armillei, 2017; Ceyhan \& Tsoukala, 2002). On the other hand, research on technologies and the security practices of control tends to focus on risk management and the mundane activities of security experts, thus downplaying the securitising role of extraordinary and elitedriven discourses (Bigo et al., 2013). Though different perspectives on securitisation provide a unique insight into the process in their own right, they also tend to entrench themselves in their respective security logics and pathways. An unintended consequence of most securitisation research is marginalisation of voices and aspects of security that do not fall under the assumed logics and parameters. That is why in this book I propose a less rigid and more inclusive way of analysing securitisation and put forward framing as one of the theories that could expand and reinvigorate the debate. The next chapter is devoted to the notion of framing and its different conceptualisations. It discusses its main theoretical building blocks and prepares grounds for its incorporation into the securitisation framework.

\section{References}

Abrahamsen, R. (2005). Blair's Africa: The politics of securitization and fear. Alternatives: Global, Local, Political, 30(1), 55-80.

Abulof, U. (2014). Deep securitization and Israel's “Demographic Demon”. International Political Sociology, 8(4), 396-415. https://doi.org/10.1111/ips.12070

Armillei, R. (2017). Boat arrivals and the "threat" to Italian national security: Between a "moral panic" approach and the EU's failure to create a cohesive asylum-seeking policy. Journal of Applied Security Research, 12(1), 141-159. https://doi.org/10.1080/19361610.2017.1228423

Austin, J. L. (1975). How to do things with words. Oxford University Press.

Bagge Laustsen, C., \& Wæver, O. (2000). In defence of religion: Sacred referent objects for securitization. Millennium: Journal of International Studies, 29(3), 705-739. https://doi.org/10.117 $7 / 03058298000290031601$

Balzacq, T. (2005). The three faces of securitization: Political agency, audience and context. European Journal of International Relations, 11(2), 171-201. https://doi. org/10.1177/1354066105052960

Balzacq, T. (2010). Constructivism and securitization studies. In M. D. Cavelty \& V. Maurer (Eds.), The Routledge handbook of security studies (pp. 56-72). Routledge.

Balzacq, T. (Ed.). (2011). Securitization Theory: How security problems emerge and dissolve. Routledge. 
Bigo, D. (2000). When two become one. Internal and external securitizations in Europe. In M. Kelstrup \& M. C. Williams (Eds.), International relations theory and the politics of European integration. power, security and community (pp. 171-204). Routledge.

Bigo, D. (2002). Security and immigration: Toward a critique of the governmentality of unease. Alternatives, 27(1), 63-92. https://doi.org/10.1177/03043754020270S105

Bigo, D. (2014). The (in)securitization practices of the three universes of EU border control: Military/Navy - Border guards/police - Database analysts. Security Dialogue, 45(3), 209-225. https://doi.org/10.1177/0967010614530459

Bigo, D., \& McCluskey, E. (2018). What Is a PARIS approach to (in)securitization? Political anthropological research for international sociology. The Oxford Handbook of International Security, 1-18. https://doi.org/10.1093/oxfordhb/9780198777854.013.9

Bigo, D., Bonditti, P., \& Olsson, C. (2013). Mapping the European field of security professionals. In D. Bigo, S. Carrera, E. Guild, \& R. B. J. Walker (Eds.), Europe's 21st century challenge: Delivering liberty (pp. 49-65). Ashgate.

Bourbeau, P. (2011). The securitization of migration. Routledge.

Bourbeau, P. (2015). Migration, resilience and security: Responses to new inflows of asylum seekers and migrants. Journal of Ethnic and Migration Studies, 41(12), 1958-1977. https://doi. org/10.1080/1369183X.2015.1047331

Buraczyński, R. (2015). Sekurytyzajca polskiej polityki migracyjnej a sytuacja przygranicznych regionów Polski wschodniej. Studia Migracyjne - Przeglad Polonijny, 1(155), 85-109.

Buzan, B. (1991). People, states and fear: An agenda for international security studies in the postCold War Era. Lynne Rienner Publishers.

Buzan, B. (1997). Rethinking security after the Cold War. Cooperation and Conflict, 32(1), 5-28. https://doi.org/10.1177/0010836797032001001

Buzan, B., \& Hansen, L. (2009). The evolution of international security studies. Cambridge University Press.

Buzan, B., \& Wæver, O. (1997). Slippery? Contradictory? Sociologically untenable? The Copenhagen school replies. Review of International Studies, 23(02), 241-250. http://journals. cambridge.org/abstract_S0260210597002416

Buzan, B., Wæver, O., \& de Wilde, J. (1998). Security: A new framework for analysis. Lynne Rienner Publishers.

C.A.S.E. (2006). Critical approaches to security in Europe: A networked manifesto. Security Dialogue, 37(4), 443-487. https://doi.org/10.1177/0967010606073085

C.A.S.E. (2007). Europe, knowledge, politics engaging with the limits: The c.a.s.e. collective responds. Security Dialogue, 38(4), 559-576. https://doi.org/10.1177/0967010607085002

Ceyhan, A., \& Tsoukala, A. (2002). The securitization of migration in western societies: Ambivalent discourses and policies. Alternatives: Global, Local, Political, 27(1), 21-39. https://doi.org/10.1177/03043754020270S103

Corry, O. (2012). Securitisation and "riskification": Second-order security and the politics of climate change. Millennium - Journal of International Studies, 40(2), 235-258. https://doi. org/10.1177/0305829811419444

Côté, A. (2016). Agents without agency: Assessing the role of the audience in securitization theory. Security Dialogue, 47(6), 541-558. https://doi.org/10.1177/0967010616672150

Emerson, R. G. (2017). Towards a process-orientated account of the securitisation trinity: The speech act, the securitiser and the audience. Journal of International Relations and Development. https://doi.org/10.1057/s41268-017-0110-4

Floyd, R. (2007). Towards a consequentialist evaluation of security: Bringing together the Copenhagen and the Welsh schools of security studies. Review of International Studies, 33(2), 327-350. https://doi.org/10.1017/S026021050700753X

Floyd, R. (2016). Extraordinary or ordinary emergency measures: What, and who, defines the 'success' of securitization? Cambridge Review of International Affairs, 29(2), 677-694. https://doi. org/10.1080/09557571.2015.1077651

Hansen, L. (2011). The politics of securitization and the Muhammad cartoon crisis: A post-structuralist perspective. Security Dialogue, 42(4-5), 357-369. https://doi. org/10.1177/0967010611418999 
Huysmans, J. (1995). Migrants as a security problem: Dangers of "securitizing" societal issues'. In R. Miles \& D. Thranhardt (Eds.), Migration and European integration: The dynamics of inclusion and exclusion. Pinter.

Huysmans, J. (1998). The question of the limit: Desecuritisation and the aesthetics of horror in political realism. Millennium: Journal of International Studies, 27(3), 569-589. https://doi. org/10.1177/03058298980270031301

Huysmans, J. (2000). The European Union and the securitization of migration. Journal of Common Market Studies, 38(5), 751-777. https://doi.org/10.1111/1468-5965.00263

Huysmans, J. (2006). The politics of insecurity: Fear, migration and asylum in the EU. Routledge. https://doi.org/10.1057/palgrave.jird.1800148

Huysmans, J. (2014). Security unbound: Enacting democratic limits. Routledge.

Jarvis, L., \& Legrand, T. (2017). 'I am somewhat puzzled': Questions, audiences and securitization in the proscription of terrorist organizations. Security Dialogue, 48(2), 149-167. https://doi. org/10.1177/0967010616686020

Jeandesboz, J. (2016). Smartening border security in the European Union: An associational inquiry. Security Dialogue, 1-18. https://doi.org/10.1177/0967010616650226

Kaunert, C., Léonard, S., \& Hoffmann, U. (2013). Venue-shopping and the role of non-governmental organisations in the development of the European Union asylum policy. Comparative Migration Studies, 1(1), 179-200. https://doi.org/10.5117/CMS2013.1.KAUN

Lazardis, G. (2011). Security, insecurity and migration in Europe. Routledge.

Leonard, S., \& Kaunert, C. (2019). Refugees, security and the European Union. Routledge.

Lund Petersen, K. (2012). Risk analysis - A field within security studies? European Journal of International Relations, 18(4), 693-717. https://doi.org/10.1177/1354066111409770

McDonald, M. (2008). Securitization and the construction of security. European Journal of International Relations, 14(4), 563-587. https://doi.org/10.1177/1354066108097553

McSweeney, B. (1996). Identity and security: Buzan and the Copenhagen school. Review of International Studies, 22(1), 81-93. https://doi.org/10.1017/S0260210500118467

Neal, A. W. (2009). Securitization and risk at the EU border: The origins of FRONTEX. Journal of Common Market Studies, 47(2), 333-356. https://doi.org/10.1111/j.1468-5965.2009.00807.x

Patomäki, H. (2015). Absenting the absence of future dangers and structural transformations in securitization theory. International Relations, 29(1), 128-136. https://doi.org/10.117 7/0047117814526606e

Peoples, C., \& Vaughan-Williams, N. (2015). Critical security studies: An introduction (2nd ed.). Routledge.

Pram Gad, U., \& Lund Petersen, K. (2011). Concepts of politics in securitization studies. Security Dialogue, 42, 315-328. https://doi.org/10.1177/0967010611418716

Rasmussen, M. V. (2006). Risk society at war terror, technology and strategy in the twenty-first century. Cambridge University Press.

Rosaldo, M. Z. (1982). The things we do with words: Ilongot speech acts and speech act theory in philosophy. Language in Society, 11(2), 203-237. http://www.jstor.org/stable/4167311

Rothe, D. (2016). Securitizing global warming: A climate of complexity. Routledge.

Salter, M. B. (2008a). Imagining numbers: Risk, quantification, and aviation security. Security Dialogue, 39, 243-266. https://doi.org/10.1177/0967010608088777

Salter, M. B. (2008b). Securitization and desecuritization: A dramaturgical analysis of the Canadian Air Transport Security Authority. Journal of International Relations and Development, 11(4), 321-349. https://doi.org/10.1057/jird.2008.20

Schmitt, C. (2010). Political theology: Four chapters on the concept of sovereignty. University of Chicago Press.

Searle, J. R. (1969). Speech acts. Cambridge University Press. https://doi.org/10.1017/ CBO9781139173438

Skleparis, D. (2016). (In)securitization and illiberal practices on the fringe of the EU. European Security, 25(1), 92-111. https://doi.org/10.1080/09662839.2015.1080160

Sperling, J., \& Webber, M. (2019). The European Union: Security governance and collective securitisation. West European Politics, 42(2), 228-260. https://doi.org/10.1080/0140238 2.2018 .1510193 
Stritzel, H. (2007). Towards a theory of securitization: Copenhagen and beyond. European Journal of International Relations, 13(3), 357-383. https://doi.org/10.1177/1354066107080128

Stritzel, H. (2011). Security, the translation. Security Dialogue, 42(4-5), 343-355. https://doi. org/10.1177/0967010611418998

Stritzel, H. (2012). Securitization, power, intertextuality: Discourse theory and the translations of organized crime. Security Dialogue, 43(6), 549-567. https://doi. org/10.1177/0967010612463953

Stritzel, H., \& Chang, S. C. (2015). Securitization and counter-securitization in Afghanistan. Security Dialogue, 46(6), 548-567. https://doi.org/10.1177/0967010615588725

Taureck, R. (2006). Securitization theory and securitization studies. Journal of International Relations and Development, 9(1), 53-61. https://doi.org/10.1057/palgrave.jird.1800072

van Munster, R. (2009). Securitising immigration. The politics of risk in the EU. Palgrave Macmillan. https://doi.org/10.1057/9780230244955

Vaughn, J. (2009). The unlikely securitizer: humanitarian organizations and the securitization of indistinctiveness. Security Dialogue, 40(3), 263-285. https://doi. org/10.1177/0967010609336194

Vuori, J. A. (2008). Illocutionary logic and strands of securitization: Applying the theory of securitization to the study of non-democratic political orders. European Journal of International Relations, 14(1), 65-99. https://doi.org/10.1177/1354066107087767

Wæver, O. (1995a). Identity, integration and security: Solving the sovereignty puzzle in E.U. studies. Journal of International Affairs, 48(2), 389-431.

Wæver, O. (1995b). Securitization and desecuritization. In R. D. Lipschutz (Ed.), On security (pp. 46-76). Columbia University Press.

Wæver, O. (1999). Securitizing sectors? Cooperation and Conflict, 34(3), 334-340.

Wæver, O. (2004). Aberystwyth, Paris, Copenhagen new "schools" in security theory and their origins between core and periphery. Security Studies, 17-20. http://bespo.org/upload/93a145a 3a12b1b8aa2e33c1ebd320d91.pdf

Wæver, O. (2011). Politics, security, theory. Security Dialogue, 42(4-5), 465-480. https://doi. org/10.1177/0967010611418718

Wæver, O., Buzan, B., Kelstrup, M., \& Lemaitre, P. (Eds.). (1993). Identity, migration and the new security agenda in Europe. St. Martin's Press.

Watson, S. (2012). 'Framing' the Copenhagen School: Integrating the literature on threat construction. Millennium, 40(2), 279-301. https://doi.org/10.1177/0305829811425889

Wilkinson, C. (2007). The Copenhagen school on tour in Kyrgyzstan: Is securitization theory useable outside Europe? Security Dialogue, 38(1), 5-25. https://doi.org/10.1177/0967010607075964

Williams, M. C. (2003). Words, images, enemies: Securitization and international politics. International Studies Quarterly, 47(4), 511-531. https://doi.org/10.1046/j.0020-8833.2003. 00277.x

Open Access This chapter is licensed under the terms of the Creative Commons Attribution 4.0 International License (http://creativecommons.org/licenses/by/4.0/), which permits use, sharing, adaptation, distribution and reproduction in any medium or format, as long as you give appropriate credit to the original author(s) and the source, provide a link to the Creative Commons license and indicate if changes were made.

The images or other third party material in this chapter are included in the chapter's Creative Commons license, unless indicated otherwise in a credit line to the material. If material is not included in the chapter's Creative Commons license and your intended use is not permitted by statutory regulation or exceeds the permitted use, you will need to obtain permission directly from the copyright holder.

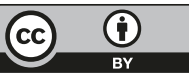

